\title{
V/STOL 機の解析と推奖する技術的手段*
}

W. H. STATLER ${ }^{* *}$

航空の歴史を通して人問は常に，ほとんどまたは全 く前進速度なしに垂直に離着陸を行なう望みを抱いて きた. この望みは多分自然の飛行家である鳥の多くが この能力を備えているという事実に由来する，鳥がそ の能力を有し人間もまたこれを望むのは VTOL（垂 直離着陸)が疑もなく有用でかつ実際的であかかて ある.

近年，われわれは V/STOL（垂直または短矩雕着 陸）飛行に対する努力のなみなみなら強化を見てき た. 多くの異なった概念に基つくく多くの新機軸の飛行 機が現われ試験された．その多くは失敗し，幾つかは 成功したが，実際に生産に入るか実用機に用いられた ものは全くない，重要なことは，これまで成された努 カにもかかわらず，真に成功裡に今日活躍している V/STOL 機はへリコプタだということである.

われわれは回転翼機の性能が固定翼機のそれと比痛 し得るものとなり, しかもなおすばらしい垂直離陸, 着陸および空中浮遊能力を備えている点にまで実際に 到達したのである.したがってほとんどすべての V/ STOL 機設計の研究に当たって，回転翼機を候補に押 すことが真剣に考えられねばならない.したがってま たわれわれが V/STOL 機の近い将来を考えるとき，

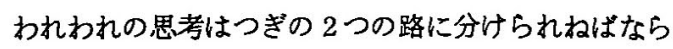
ない.

1. 進んだ回転翼の概念

2. 他の直接揚力 V/STOL の概念

上の立場を述へる別の方法がある. それは設計者が ヘリコプタから出発し，それを固定翼機と比較し得る 巡航速度に持ってゆくか，または基本的には飛行機の 設計から出発して, それに揚カエンジンやその他の垂 直推進の特別な方法を付加して垂直離着陸性を与える かである.

この論文では両方からの到達を考えることにする. 使用速度範囲の重なり合っている樣子は第 1 図に示さ れる. 非常に高性能の飛行機, 例えば超音速戦斗機の ようなものを除いては，ある種の進んだ回転翼機が合 理的な競争者たり得る.

* 1966 年度日本航空学会年会 (4 月8 日) て蛅演. 昭和 41 年 6 月 3 日原掅觉理

** Deputy Director of Engineering, Lockheed-California Company. 要訳 東京大学宇宙舫空研究底 東昭

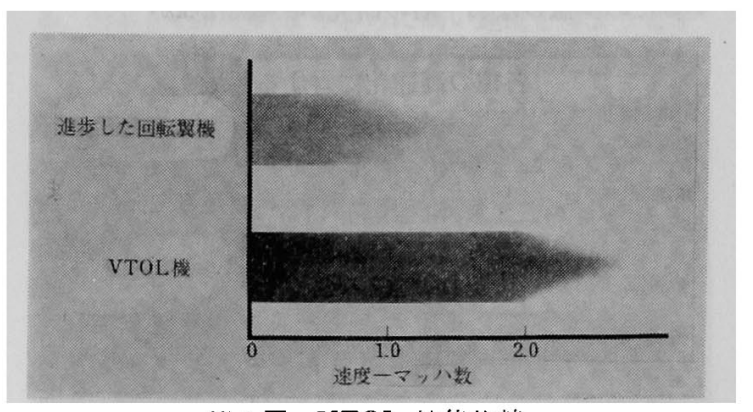

第 1 図 VTOL 性能比較

高速ヘリコプタ

ヘリコプタはその全く独自の特徽のゆえに航空界に 批いてそれ自身永久地位を確立し，かつその最適の仕 事は他の如何なる㯕念に基つくく機種によっても置き換 えられそうにない，最近の研究は至るところでへリコ ブタの速度能力の増加に向けられてきた．私は速度が 第 2 図のように多くの重要な報酬を約束するので， 人

高速で改良される事項…

\begin{tabular}{|l|}
\hline 直接運航費 \\
生存可能生 \\
応 答 時 間 \\
定時発着性 \\
\hline
\end{tabular}

第 2 図高速化の利点

リコプタ利用の搪大を計る最良の方法はその速度能力 の伸展にあることを信ずる.より高速の前進飛行はそ れ自体他の型の飛行機同様に民間用と軍用輸送機にと ってより安い直接運航費に変わる。

直協機では高速ほど生き残る率も高くなるようであ る. 対ゲリラ戦用飛行機では, ASW (対替攻撃) 機 同様, 高速機ほど応答時間も目標までの時間も少なく なることを意味し，役目遂行上の改良をきたすもので ある. ASW パトロール機や他の役割の機体では, 主 たる飛行距離と滞空時間は乗員の滞空時間で定まって しまう生理的な限界で, 高速は目的地までの程過時間 を減少ししたがって目的地における滞空時間は多く なる.

いろいろな試みの設計により高速へリコプタの完成 
を目指しているが，そのすへてがヘリコプタにとって さらに複雑さとそれに伴う重量の增加をもたらすよう である. 幾つかの実現されそうな例が第 3 図に示され ているが，その多くはそれらが運航計画に実用される 以前に技術的な可能性を達成し，十分な信賴度を確立 するため多量のなお一層の研究が必要である.

\section{各種の高速化に対する手段}

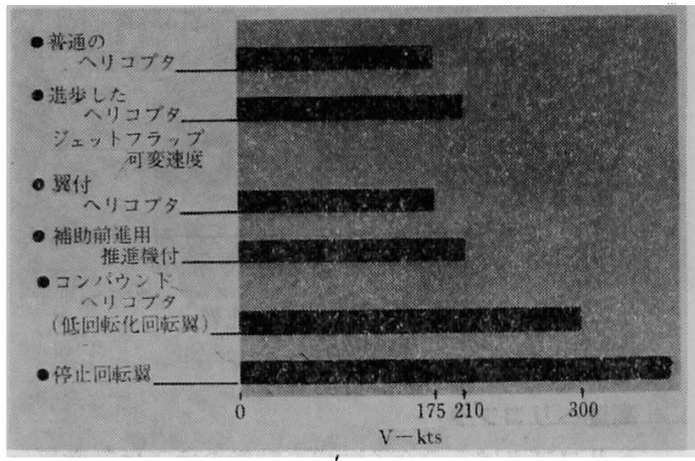

第 3 図 VTOL 速度スペクトル

ところで安定性や操縦性あるいは振動の水望を犠牲 にして速度を上げるのでは有用な速度を与えたことに はならない：実際へリコプタの応用し得る広いスペク トルを通じて，すべての潜在的な成果がそれ自身の面 でれぞれ有効で応用可能でるが，重要なことはわ れわれが性能要求を注意深く確認し, 決して無茶な計 画て㬰際の必要性を越えてまで複雑さを生ずることの ないようにすることである.

純へリコプタの単純性を保持したままで幾つか進ん だ概念のむのが考えられ，速度において 15\% の性能 改良を得る.このことは最も重要な現用へリコプタの 多くに適用した場合優れた効果を発掉する.コンパウ ンド・ヘリコプタは，われわれが翼を付け加えること で高速時に揚力を出し，また前方推力エンジン取り 付けることで高速時の推力を生ずるので，回転翼の荷 重をなくしその無負荷になった回轱翼が低回転にされ るかされないかに応じて，40\% から $70 \%$ の速度向上 の可能性を提供する.

前進飛行時に回転翼を完全に停止することですちろ ん最大前進飛行速度を制限している要秦のすべてが消 され，実用性と普通の飛行機抵抗の範囲内て望まれる ような高速の前進飛行速度が可能になる.しかし前進 飛行速度の增加と重量, 価格および複雑さの増大とい ったものとの間の取り引きが，特定の使用目的に対し て注意深く検討されねばならない，考えるべき重要な 点は，われわれが目前に飛行可能速度についての新し い広いスペクトルを持っていることて，ヘリコプタの 比較的低い前進飛行速度の限界はなくなるであう。

\section{背 景}

剛性回転翼 (rigid rotor) の高速性のこの議論の段 階で私はます今日まての背景の総括を述べてみたい。 多くの飛行と風洞試験計画が遂行され，㓮性回転へリ コプタの技術的な実現可能性と高速を実現する際の滆 性回転翼の適用性との決定が追求されてきた。

ロッキードの初期の飛行研究計画はロッキードCL475 (第 4 図) て約半年前に始められた。この計画は

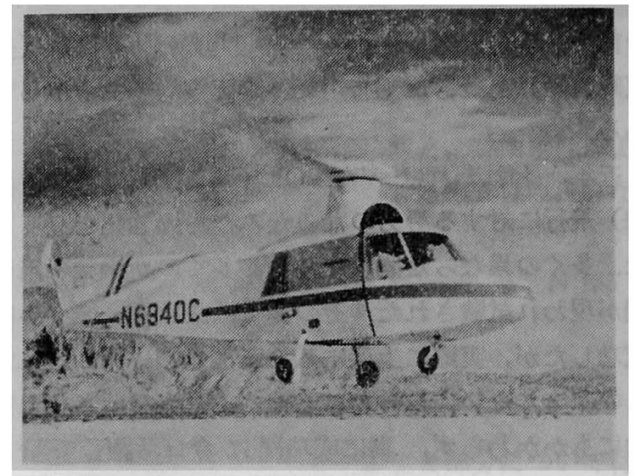

第 4 図 CL-475 研究へリコプタ

㓮性回転翼の技術的な実現可能性と設計概念の開発に 向けられた。 われわれは羽根の数，斜板に対する羽根 の取り付けおよび羽根装置の最良空弾性特性を達成す る方法といった幾つかの要因をしらべた。

XH-51 A (第 5 図) は合衆国陸軍，海軍およびロッ

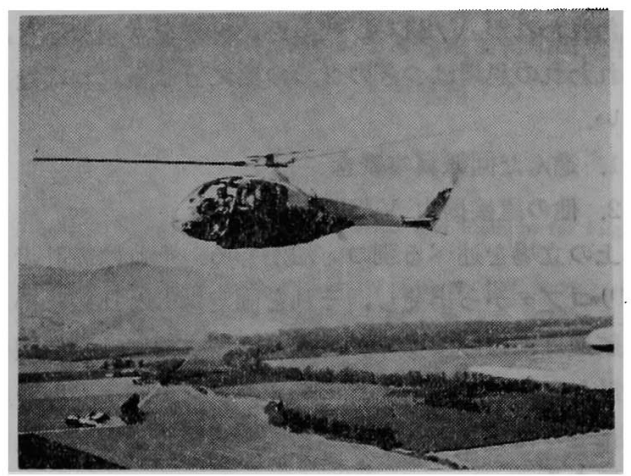

第 5 図 XH-51 A 研究へリコプタ ( 3 枚羽根回転翼)

キードの合同計画であったそそれはわれわれが振動， 羽根の荷重, 機体性能およびその他の多くの要因を探 求することの出来る非常にうまい飛行実験機を与えて くれた. コンパウンド・ヘリコプタ分野に対するわれ われの飛行実験の実施は 2 つ面で進められた。第 1 は初めの 3 枚羽根の XH-51 の代わりに 4 枚羽根の回 転翼の飛行実験であった，われわれの抱くコンパウン ド・ヘリコプタの仕様はこれより重い重量て，したが 
ってょり大きい円板荷重の機体を考えているのでこ れは重要な予䎜的段階であると思われた．このことは また高いソリディティ（solidity）の回転翼を必要とし た. 第 2 は 4 枚羽根の回転翼が前進飛行のための短翼 (stub wing) と，ジェット・エンジンのある機体に 取り付けられ，コンパウンド・ヘリコプタに剈性回転 翼を適用した場合の技術的な実現可能性について決定 的な飛行試験による評価を与えることであった．第 6

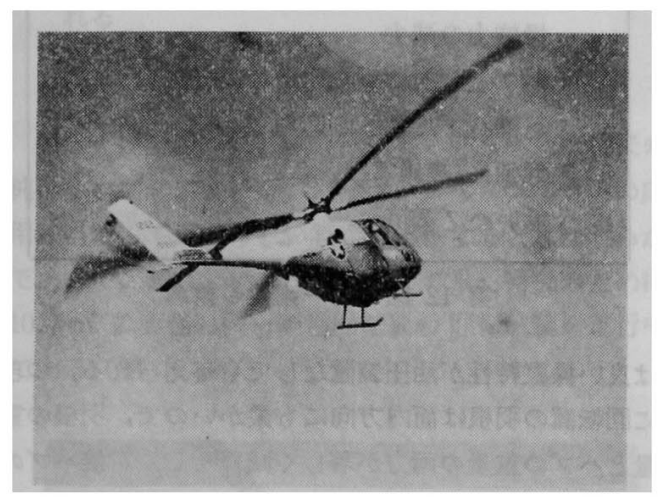

第6 图 4 枚羽根剛性回転翼 XH51 A

図は $\mathrm{XH}-51$ 型および目下連邦航空局 (FAA) の証 明を取りつつある民間用ロッキード 286 型機に用い られている既に開発された 4 枚羽根剛性回転翼を示し ている， XH-51 型純へリコプタの我行実施計画は実 際に作動しているヘリコプタの技術的要素のすべてを 調冝するために企てられた（第 7 図).

NH-51 型純へリコプタで示された飛行範囲は第 8 図に示されている。.この飛行実験を集約して，网性回

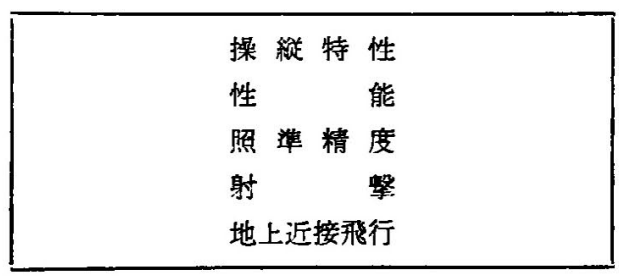

第 7 図 XH-51 飛行実験計画

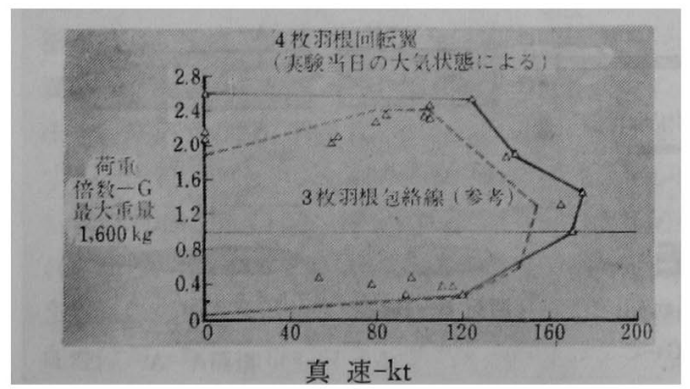

第 8 図 XH-51 飛行実殹 $\mathrm{V} \sim \mathrm{n}$ 包絡線
転翼は技術的に実現可能であり，剛性回転翼を採用し たヘリコプタは優秀な飛行特性を示すといってよい.

主回転翼が全揚力と全推力を作り出すような純へリ コプタでは，いずれむ回転翼の抵抗または振動が十分 高くなって機体の前進速度を制限するような点があ る.われわれがそれよりさらに高い速度を得ようとす ると，例えば翼のような揚力面と追加された前方推進 䒾固とを備えることが必要で，これにより主回転翼は 抵抗と振動を減少するためにピッチを零にすることが できる.ロッキードの XH-51 A の“コンパウンド” 型は第 9 図に示されている.

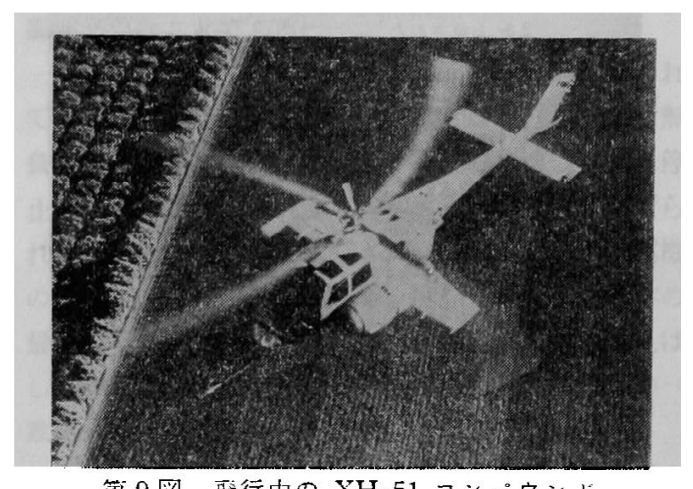

第9図我行中の XH-51 コンパウント

コンパウンド・ヘリコプタに剖性回転翼の適用を考 えた場合, われわれは XH-51に関する飛行実験から ヘリコプタおよび飛行機の両飛行状態に対する 2 系統 操縦の必要性をなくすことが第 1 の要素であることを 発見した，操絽が主として推力を傾けることて得られ る普通のすなわち関節式回転翼装置では, 操赫可能範 囲は回転翼が無負荷にされると減少する. 通常昇降航 や補助翼を含を飛行機式の補助翼操維装置が前進飛行 時に要求される，剛性回転翼はその操緃を主として回 転翼頭部で直接伝達されるモーメントを通じて得ると いう回転翼型式である.この操綐型式は回転翼が荷重 下にあろうと無負荷であろうと同じであるのて，前進 飛行中飛行機式の補助の操綐は何ら必要がない.

高進行率ての飛行ては過渡的な羽根の荷重や振動が 主として問題となり，しばしば過酷な使用状態下での 㓮性回転系に生ずる羽根の荷重と㤁力とがどんなむの かという䓄問を受ける. 剛性回転翼の概念は初めはフ ラップ方向の如何なる過渡的な荷重をむ自ら解放する ために開発されたもので，高い荷重すなわち高い応力 を異常に受けることはない. $\mathrm{XH}-51$ コンパウンド計 画の成果は第 10 図に示されている.

最近のコンパウンド飛行実験でわれわれは $\mathrm{XH}-51$ コンパウンド機の飛行籍囲をさらに拡张した（第 11 困). 飛行実験計画は剛性回枟翼のコンパウンド・へ 
コンパウンド研究機飛行状況

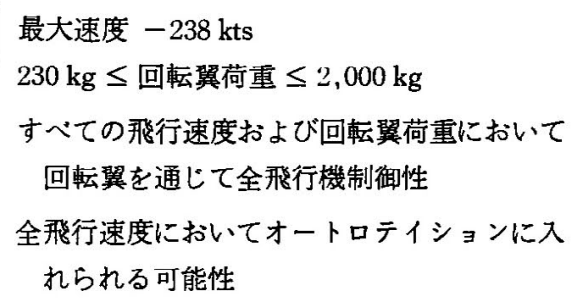

第 10 図 コンパウンド機飛行状況

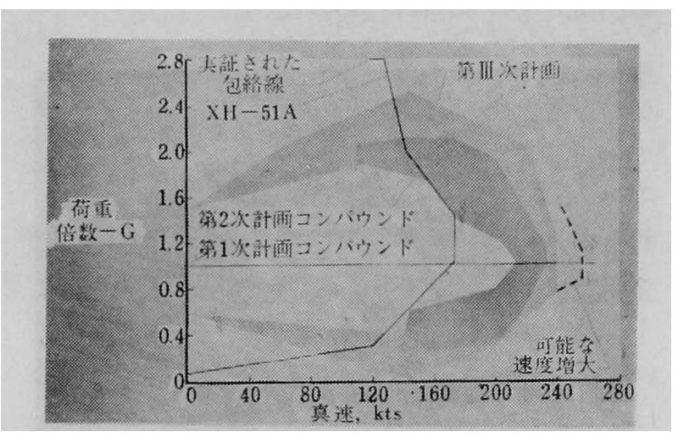

第 11 図 コンパウント XH-51 飛行実䮖 $\mathrm{V}-\mathrm{G}$ 包絡線

リコプタへの応用に対して十分その適用性を示し，わ れわれは非常に元気づけられている.

\section{進んだ回転露の概念}

つぎに私はわれわれのもっと進んだ㴊性回転翼の概 念のあるむのについてお話したいと思う.これらのも のの中最も興味のある一つは，いわゆる同一㓮性回転 翼と呼ばれるものである．その理念は割合簡単であ る. 羽根の面内方向における構造㴊性とフラップ方向 におけるそれとを一致させることで，羽根装置の合成 されたフラップ方向および面内方向の変形に基つく羽 根のフェザリング軸まわりのいかなるモーメントもな くせるようになっている(第 12 困).

同一剛性回転翼の概念は多くの㪚力ある特徴を 示すので，進んだ純へリコプタ特に非常に高い揚 カを出すへリコプタやコンパウンド・ヘリコプタ に応用した場合に興味が持たれる．まず第 1 に面 内とフラッピング方向の変形がいっしょにされる と最早フェザリング軸のまわりに変形によるモー メントが生じなくなるので，羽根のフェザリング の慣性, したがって安定化ジャイロの慣性が著し く減少され得る.このことはへリコプタに良い応 答性を与えるために低い操粉力でよいことにな る. 小型へリコプタ例えば XH-51 程度の機体で

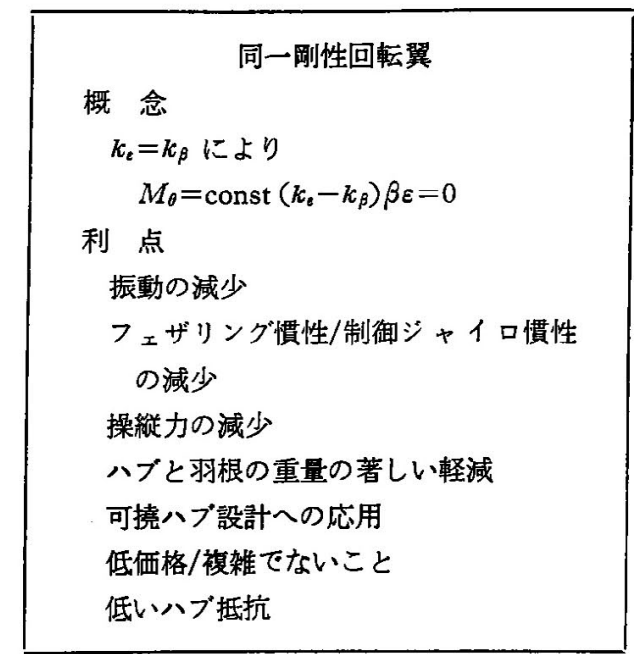

第 12 図 同一剛性の概念

は良い操䋛特性が油压装置なしでも与えられる。つぎ に回転翼の羽根は面内方向にも柔かいのて，羽根の重 量とハブの重量の両方が著しく減らせる. 可摬ハブの 典型的な同一㓮性回転翼系の一例が第 13 図に示され ている.

現在のところ同一㓮性の羽根を持った成性回転翼の 重量評価は普通の㴊性回転翼のそれの $3 / 4$ である. この羽根はフラッピングと面内との両方向に采かいの で，据り軸に関してもまた柔かく，したがって可撓八 プ設計にうまく合致している。これはフェザリング軸 受の值段と複雑さを軽減している.

最後にハブの抵抗減少による高速化の実現で著しい 改良がなされた．この結果装置からヒンジがなくなり 外部の制御ジャイロがなくなり，またフェザリング軸 受むなくなった。

同一魝性回転翼の風洞武験結果の幾つかが第 14 図 に示されている。この計画には遷音速風洞に入れた $1 / 3$ 縮尺の動的に相似な風洞模型が用いられた，風洞 試駼の結果を外插して，適当に釣合をとった回転翼で は $300 \mathrm{kt}$ の飛行が可能であることを示している.

\section{CL-864 同一剛性/可撓羽根}

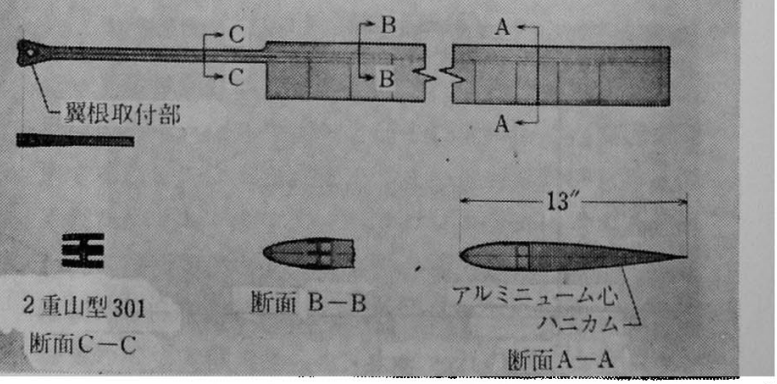

第 13 図 同一用性回卙虽 


\begin{tabular}{|c|c|c|c|}
\hline 速 度 & & 風洞試験 & 予 測 \\
\hline \multirow{2}{*}{ 負 荷 } & 速 度 & $165 \mathrm{kt}$ & $200 \mathrm{kt}$ \\
\hline & $\mu$ & .46 & .56 \\
\hline \multirow{2}{*}{ 無負荷 } & 速 度 & $230 \mathrm{kt}$ & $300 \mathrm{kt}$ \\
\hline & $\mu$ & .91 & 1.19 \\
\hline
\end{tabular}

太面内荷重は普通の実機の場合の $1 / 3$ から $1 / 10$ ネ空中/地上の（コルマン）共振が容易に避けら れる

\section{第 14 図 同一渆性回転翼風洞試験結果}

同一可撓羽根ハプの剛性回転翼という概念は将来の 純へリコプタおよびコンパウンド・ヘリコプタへの芯 用に当たって素晴らしい利点を提供することは明らか であって, われわれは実長寸度ての飛行研究のために $10.7 \mathrm{~m}$ の直径の同一㓮性回転翼の 回転試験を遂行中 である(第 15 図).

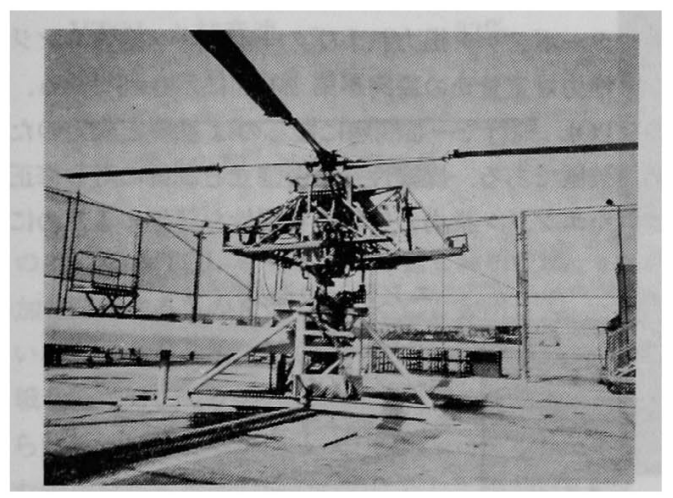

第 15 图 回転塔における同一剈性回転翼

コンパウンドの場合, 揚力を与える翼が付加されま た前進推力を与える前方推力エンジンがあるために， 主回転翼が本質的に無負荷ても回転している回転翼は なお飛行機の速度を制限する。これはある飛行速度て 回転翼の先端の進行速度が音速に達してしまうから でつぎの段階としては回転翼を止めることである.

停止回転翼は㴊性回転翼が特にうまく適用される高 速化への別の例である. 考えられる 2 種の停止回転翼 機が第 16 図に示されている. まず初めは主翼一回䢂 翼という概念のむので, 荷重は回転翼の停止のために 小さい高揚力の翼に移される. いったん回転翼が停止 すると, 翼のフラップが引き込まされて揚力負担が回 転翼の羽根に戻される. 約 $120 \mathrm{kt}$ て回転翼が止めら れてから，機体は $250 \mathrm{kt}$ の近辺の最高速度で飛行出 来る. この種の停此回転翼機の最大前進飛行速度の可 能性は同一剛性羽根のコンパウンド・ヘリコプタで期 待されるものと同様である.この型式の欠点はへリコ

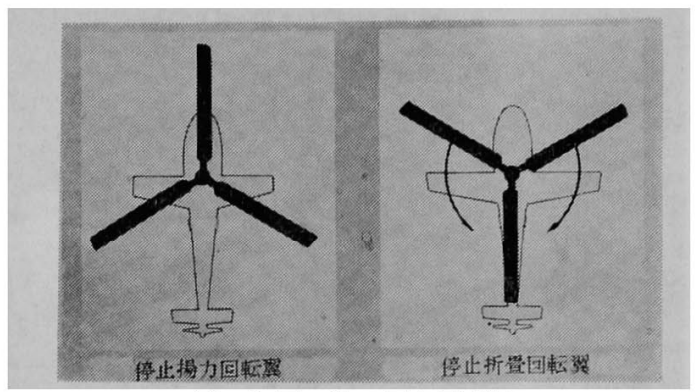

第 16 図 停止回転翼概念

プタとして飛行状態の制御の他に固定翼機としての制 御が必要なことである.

第 2 の型の停止回転翼機は第 16 図の右側に示され ている、この場合には, 羽根は約 $120 \mathrm{kt}$ て同様に無 負荷にされ揚力は翼に移される．回転翼がいったん停 止すると, 羽根はそれから折り畳まれて繸に引きずら れ，出来れば同体内に収納され飛行は普通の固定翼機 の状態で遂行される.この場合回転翼の羽根は機体の 最大飛行速度に対して何らの空力弾性的限界を与えは しないで，単に普通の飛行機同様推力と抵抗曲線の一 致点てのみ制限される.

$1,800 \mathrm{~kg}$ 程度の小型機では高温相当高度の浮游（ホ バ）状態に要求される動力で最大速度は約 $245 \mathrm{kt}$ が 達成される，9,000 kg の機体だと同じうに必要な 動力て $300 \mathrm{kt}$ を，また $27,000 \mathrm{~kg}$ 程度の機体ては浮 游で定まる動力で最大速度は $400 \mathrm{kt}$ を越える。

風洞試験では最大 $160 \mathrm{kt}$ て $10 \mathrm{~m} / \mathrm{s}$ の相似突風下 における停止と始動に成功した. 停止と始動中の振動 は $\pm 0.10 \mathrm{G}$ 内に改まった（第 17 図）. 回転翼は停

† $160 \mathrm{kts}$ の速度まて， $10 \mathrm{~m} /$ の突風下で

回転の停止と始動に成功

丈 振動 $\leq \pm 0.10 \mathrm{G}$

$\star$ 操潇性

$10 \mathrm{~m} /$ 突風て $1 / 3$ の補助翼操舵

零突風下て操緃不要

第 17 図停止回転翼風洞試験結果

止と始動中無負荷なので, 零突風状態ではハイロット の操綐要求は何もない，われわれは目下 $10.7 \mathrm{~m}$ 直经 の停止折り畳み回転翼に関する実長寸度の回転と風洞 試験とを行なっている. (第 18 図).

まとめるとあらゆる型の高速回轱翼機に対する応用 において，㴊性回転翼は非常に望ましい固有の特徴を 持っていることが示されたといえよう. (第 19 図). 
実寸度模型による研究

$10.7 \mathrm{~m}$ 直径回転翼

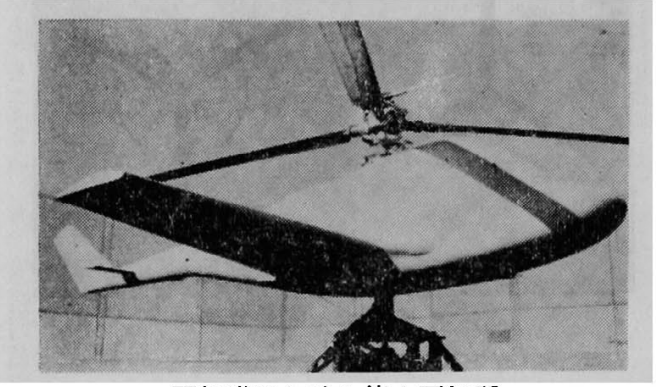

回転塔における停止回転翼

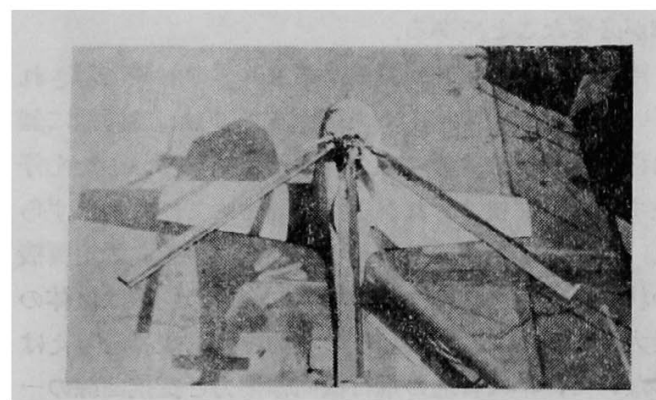

部分的な羽根の折り畳み

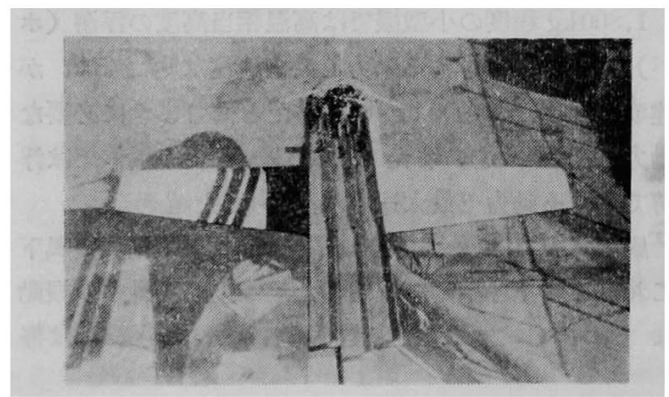

完全な羽根の折り畳み

第 18 図回転塔上の停止回転翼

\begin{tabular}{|c|c|}
\hline $\begin{array}{l}\text { 純ヘリコプタ } \\
\text { コンパウンド } \\
\text { ヘリコプタ }\end{array}$ & 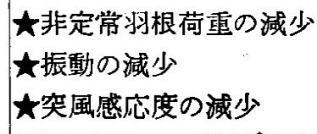 \\
\hline $\begin{array}{c}\text { コンパウンド } \\
\text { ヘリリプタ }\end{array}$ & 余分の操緃系統の消去 \\
\hline 停止回転翼 & 大㣂性回転翼の適用性 \\
\hline
\end{tabular}

第 19 圆高速飛行における㓮性回転翼の利点

私がこに浦へててきたようなまたはその他の速度の 進歩とともに、ヘリコプタはこの状態にとどまらず全 く新しいスペクトルに向かって進歩し, 回転翼機は多 くの目的に対して固定翼機と競合し始めているのであ る.

\section{直接揚力 $\mathrm{V} / \mathrm{STOL}$}

われわれの成し得る $2 つ の$ 手段の中, 通常固定翼機 の領域であるところに侵入する回転翼機のことにつき これまで多く述べてきたが，ここでは他の手段のもの すなわちスペクトルの他の端のものについて考えよ 了.

非常な高性能機例えば超音速戦斗機では，目下のと ころ停止および収納回転翼理念はあまり実際的ではな い. 高性能戦斗機は非常にまとまっているので，回転 翼装置を収納する場所を見付けることが容易でない， したがって VTOL 戦斗機への接近は一般に小型で高 効率の揚カエンジンと, ときには垂直飛行に当たって 推力偏向をはかる前進用推カエンジンとの組み合わせ を用いる方にある.

この可能性は, 推力対重量の比が 20:1 以上の直 接揚力エンジンの実現可能性や推力偏向の原理が実証 卆れているので十分期待出来る.ターボジェット揚 力, ターボファン揚力およびターボファン推カエンシ ンの推力対重量比の傾向が第 20 図に示されている.

VTOL 飛行で一番問題になるのは操縦と安定のた めの萃置である. 操綎性基準の確立と制御に対し修正 されたエンジン推力の使用の実現性を評価するために
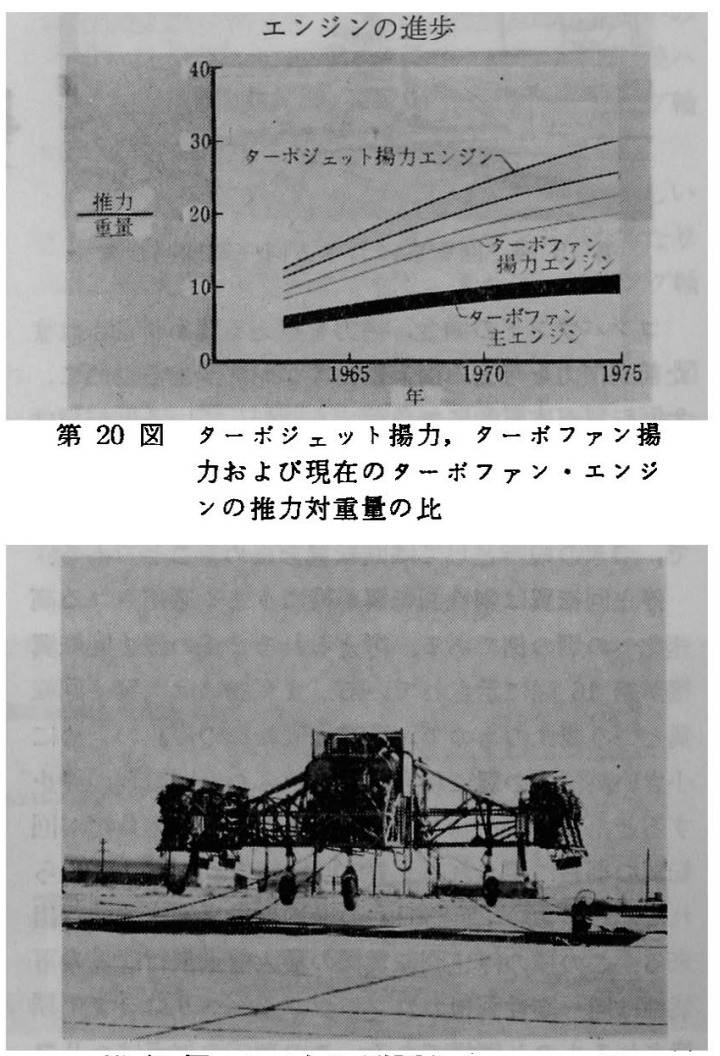

第 21 目パ中の VTOL シミュレータ 
ロッキードは VTOL 試験体を製作した（第 21 困).この機体は 6 個の G.E. J-85 エン シンンを垂直揚力のために用い，いろいろな横 ‘方向位圈にそれらが配置出来るように作られ ‘た. 試験は今日まて推力変化が実際に䋛摇れ や横摇れの制御に用いられることが出来るこ とを示したが，自信を持って VTOL 操縦性 基準を確立するにはなお多くの試験が必要て ある.この試騟体は F-104 とほぼ同じ質量 と慣性を持っている.

第 22 図は過去 10 年から 55 年にかけて の軍用飛行機の達成した新分野における進歩

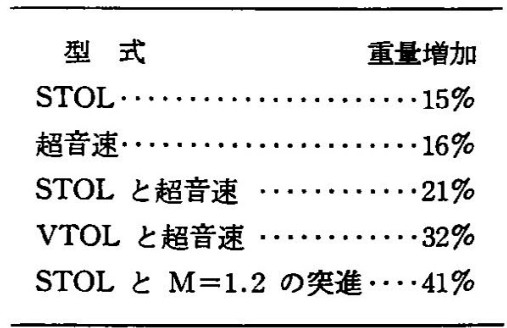

第 22 図装備空虚重量

の多くが VTOLと関連した重量と費用の增 加と匹敵するものを合んていることを示して いる. これらの重量増加は特定の亜音速艦载 戦斗機に対してなされた詳細な研究の結果得 られたものであるが VTOL の值段は進步し た性能を有する他の型のものに対して払われ る費用と比較し得るものである.

\section{短矩㒕輪送}

さて V/STOL 領域の研究で最も興味ある むのの一つは，明白に回転翼の場合と直接揚 力の場合とのちょうど中間の “扊色” の部 分の調查であ. 典型的な一例が短矩離輸送 でこれは $800 \mathrm{~km}$ ほど離れた主要都市の都 心間のための飛行バスと呼ぱれる商用輸送て ある.

各種の垂臣揚力機構を持った多くの形状の 機体が短矩離輸送のために考えられたが，そ のような飛行機か：VTOL と浮游の可能性を 持ち, 単なる STOL 可能性ではないものと するとつぎのように考えられる.

1. 揚力ファンと進行ファン

2. 傾倒翼 (tilt wing) とプロペラ

3. 傾倒回転翼

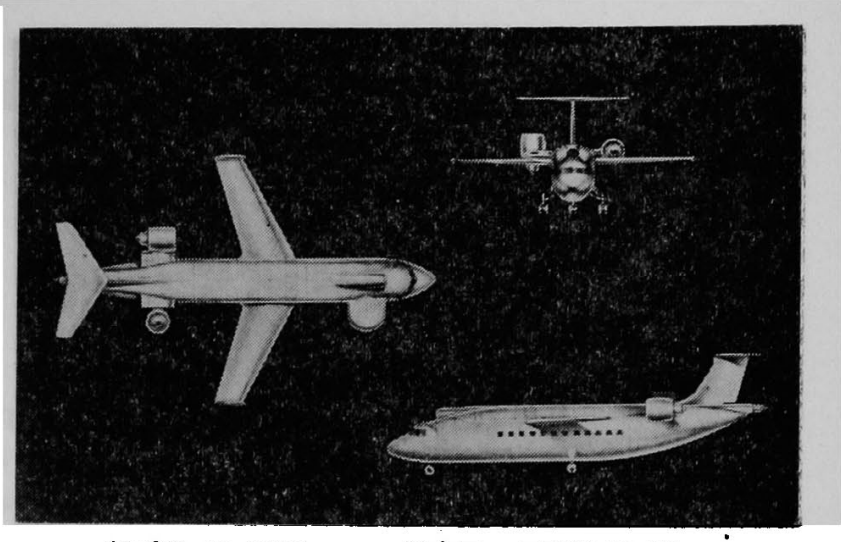

総重量 $80,100 \mathrm{lb}$ 揚力ファン直径 $91.5 \mathrm{in}$ 進行ファン直径 85.8 in エンジン $15,000 \mathrm{lb}$ 翼面稹 $667 \mathrm{ft}^{2} \quad \mathbb{R} 4$

第 23 図 揚力ファン一進行ファン VTOL

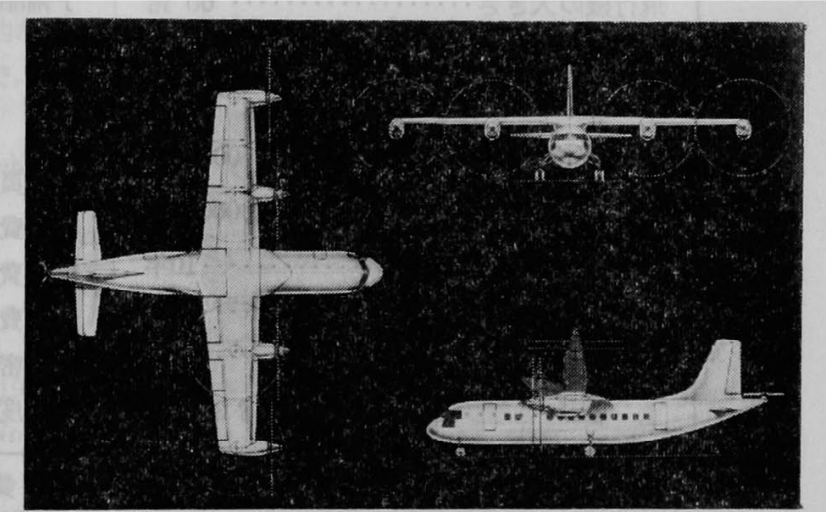

総重量 $73,000 \mathrm{lb}$ プロペラ直经 $24 \mathrm{ft}$ エン ジン 5,690 shp 翼面榡 $1,077 \mathrm{ft}^{2} \quad$ AR 7

第 24 図 4 プロペラ傾倒翼

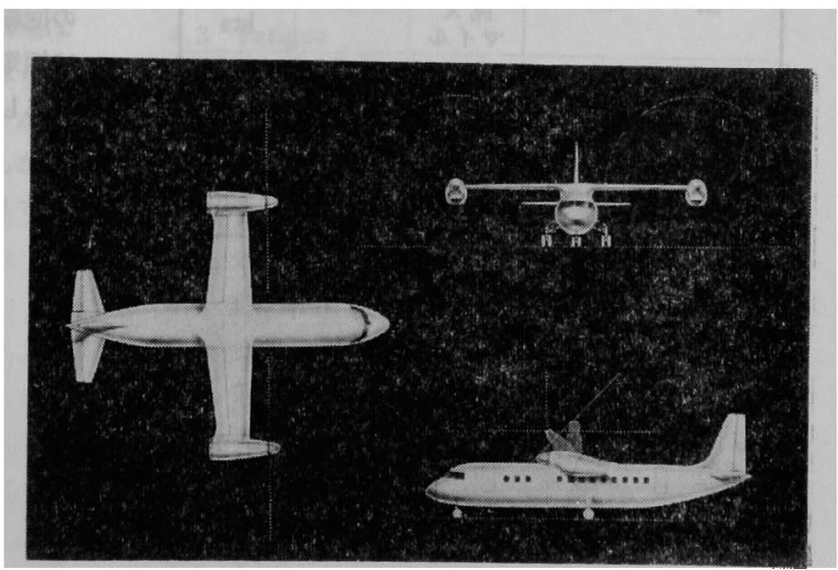

總重点 $60,900 \mathrm{lb}$

回転閴直怪 $50 \mathrm{ft}$ エンシ

3,240 shp ea

留面橉 $692 \mathrm{ft}^{2} \quad$ R 6

第 25 図傾㓡回転裂 VTOL 


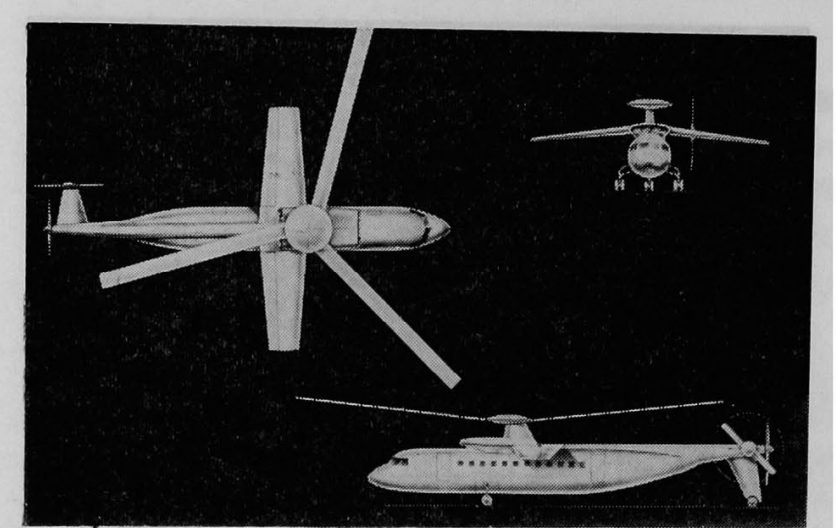

総重量 $67,350 \mathrm{lb}$ ジン $3,350 \mathrm{shp}$

回転翼直径 $92.5 \mathrm{ft}$ エン 翼面積 $561 \mathrm{ft}^{2} \quad A R 8$

第 26 困 停止回転翼(プロペラ) VTOL

\section{4. 停止と収納回転翼}

60 人乗りの飛行機を考えてみよう. 第 23 図には揚カファンと進行ファンの概念のむの が，第 24 図には傾倒翼と傾倒プロペラのも のが，第 25 図に傾倒回転翼のむのが，そ して第 26 図には停止，折り畳みおよび収納 回输翼のむのがそれぞれ示されている.

今日までの研究によれば,このような短矩 離機は経斉的に魅力のあることがわかった。 直接運航費の計算に用いられた仮定は第 27 図に示されている.

安全性, 吹き下ろし速度, 経済的な浮游特 性および騒音を考えたとき，われわれはこの ような機体としては直接揚力ファンまたはプ ロペラよりはむしろ回転翼を使用すべきであ

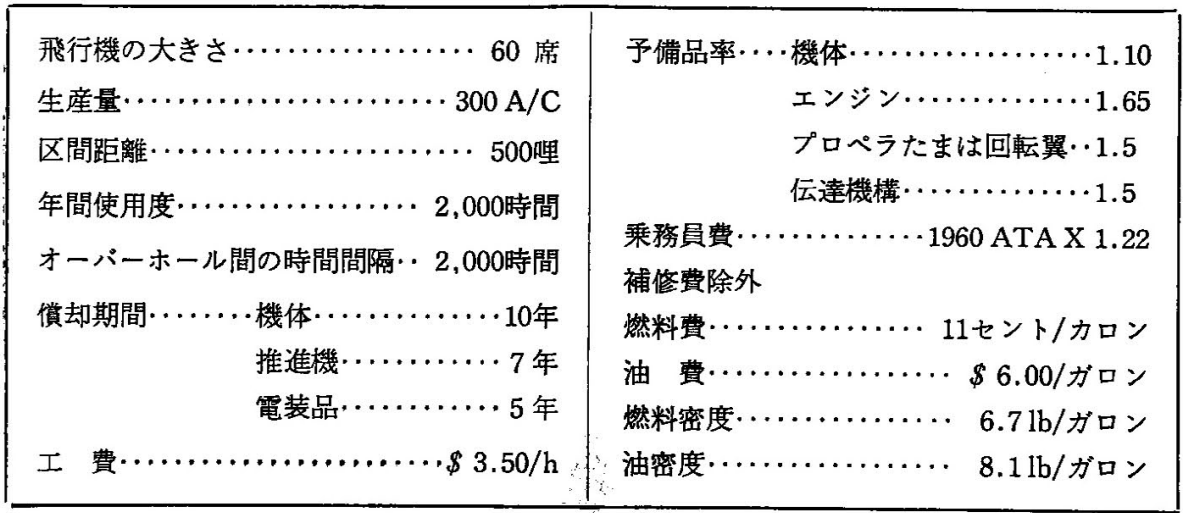

第 27 図直接運航費仮定

VTOL 短距離輸送機 (60 席)

\begin{tabular}{|c|c|c|c|}
\hline 類 & $\begin{array}{l}\text { D.O.C } \\
\text { セント } \\
\text { 席 } \\
\text { マイル }\end{array}$ & 総重量 & $\begin{array}{c}\text { 巡航速度 } \\
\mathrm{kts}\end{array}$ \\
\hline 揚力/進行ファン & 2.50 & 80,100 & 496 \\
\hline 傾倒翼 & 1.65 & 73,000 & 449 \\
\hline 傾倒回転翼 & 1.41 & 60,900 & 418 \\
\hline 停止回転翼 & 1.49 & 65,400 & 377 \\
\hline
\end{tabular}

第 28 図直接運行費総額
るとの結論に達した.この飛行機は人口稠密の都心の 内外て，しかも悪天候にもかかわらず規則正しく運航 されねばならない，騒音のことを考えると低円板荷重 の回転翼のみが考えられてくる、したがってわれわれ は短矩離輸送機としては停止と収納の回転翼の穊念が 望ましいものと思う。 